\title{
Islamic Education In West Sumatra: Historical Point Of View
}

\author{
By Rahmawati Baharuddin
}

\begin{abstract}
Paper ini berfokus pada sejarah singkat pertumbuhan dan perkembangan pendidikan Islam di Minangkabau sebelum dan sesudah munculnya gerakan pembaharuan Muhammadivah. Perkembangan pendidikan Islam itu sendiri dimulai berbarengan dengan kedatangan Islam di Sumatera Barat. Gagasan reformis gerakan Muhammadiyah dalam bidang sosial keagamaan pada abad ke-20 memberikan sumbangsih yang besar terhadap perkembangan modernisme Islam di Sumatera Barat dan telah memberikan wama terhadap sistem pendidikan di Indonesia.
\end{abstract}

\section{A. Introduction}

Many scholars have argued that the rise and growth of Islamic education in one region began with the preaching of Islam which mainly conducted through the medium of education. Mahmud Yunus, ${ }^{1}$ a great Indonesian educator, for instance, thought that Aceh, a region located at the northern tip of Sumatra, was the first part of Indonesia whose its inhabitants were converted to Islam. ${ }^{2}$

However, scholars do not agree on the exact moment that Islam was introduced into the Indonesian archipelago. This difference of opinion stems from the fact that the factual data on the earliest period of Islam in the archipelago are so scanty. Nevertheless, we can classify their opinions into two categories. The 
first group, most of them Dutch scholars, such as Pijnappel, hold the opinion that Islam was first introduced into Indonesia in the twelfth century by Shâf' $\hat{\imath}$ Arabs from Gujarat and Malabar. His opinion was based on the fact that these regions are mentioned so frequently in the early history of the Indonesian archipelago. $^{3}$

The same holds true for Snouck Hurgronje, who believed that the twelfth century was the most probable date for the Islamization of the Indonesian archipelago. His opinion was based on the fact that Islam once Islam had gained a firm hold in the port cities of South India, "the inhabitants of the Deccan, who resided in great numbers in the port cities of this island-world as middlemen in the trade between the Muslim states and the East Indies, were as if in the nature of things scatter the first seeds of the new religion. Arabs, especially those who passed for descendants of the Prophet under the name of Sayyid or Sharif, later found a welcome opportunity to demonstrate their organizational ability. As priests, priest-princes and as sultans, they often out the finishing touches to the formation of the new realm". ${ }^{4}$ Unfortunately, Snouck Hurgronje did not define in more detail which part of South India this is. On the contrary, a little further on he observed that he could not for the time being indicate the section of South India where the threads linking the spiritual life of the Indonesians with that country come together.

In line with both scholars above, Moquette asserts that Islam came into Indonesia from Gujarat, because the gravestones found in Pase district, on the coast of North Sumatra, dated Zulhijjah 17, $831 \mathrm{H} /$ September 27, $1428 \mathrm{M}$, and the gravestone of Malik Ibrahim in Gresik apparently originated from Cambay in Gujarat. $^{5}$

Taking a very different approach from the first group, the second group, most of them Eastern scholars like Naqib al-Attas, argues that the well-known theory that Islam came from India and was conveyed to the Archipelago by Indians cannot be accepted. His opinion is based on the conclusion of his study on Malay literature before the seventeenth century, in which he says that there was no religious literature written by Indians in its corpus. In addition, he stresses that analysing Malay literature itself also plays a prominent role in determining the coming of Islam to the Malay Indonesian archipelago. In fact, it is true that some works were written in India, but their origin, he argues, lies in Arabia and 
Persia, or they could even be, in comparatively small measure from Turkey or the Marocco and, what is more important, their religious content is Middle Eastern, not Indian. ${ }^{6}$

Along the same lines as Al-Attas, in their seminar on the arrival of Islam into Indonesia Indonesian Muslim scholars also concluded that Islam was first introduced by Arab traders followed by Gujarat Muslims from India in the seventeenth century. Therefore, they think that it is quite certain that Islam came to Indonesia neither in the seventeenth century or in the thirteenth century, nor that it was first introduced here from India.?

\section{B. The Rise and Growth of Islamic Education in West Sumatra}

Giving his views about the coming of Islam to West Sumatra, Hamka argued that Islam was introduced into Minangkabau through two lines. First, it spread from Malacca along the Siak River and the Kampar River by Minangkabau traders living in Malacca. ${ }^{8}$ Hamka's opinion is based on the fact that at the beginning of the fifteenth century the Straits of Malacca were very famous as a trading route. Many traders from surrounding areas converged in towns along its shores, for instance from Minangkabau. So that, the Minangkabau traders who returned to their villages were the spreaders of Islam. Secondly, it originated from Aceh and was brought directly by Shaikh Burhanuddin Ulakan. Furthermore, according to Hamka, Shaikh Burhanuddin studied with Abdul Rauf, the famous ' ulamâ during the reign of Sultan Iskandar Muda Mahkota Alam in Aceh. When he finished his studies, he came back to his natal village, Ulakan, a small region in Pariaman, and started preaching Islam there. Building a surau as the centre of his teaching, Shaikh Burhanuddin began to inculcate the ideas of Islamic education in Minangkabau. ${ }^{9}$

Taking the opposite tack to Hamka's opinion, Mahmud Yunus writes that Islam came into Minangkabau as early as $521 \mathrm{H} / \mathrm{AD} 1128$. Since Shaikh Burhanuddin lived from $1066 \mathrm{H} / \mathrm{AD} 1646$ to $1111 \mathrm{H} / \mathrm{AD} 1691 .{ }^{10} \mathrm{He}$ was neither the first spreader of Islam nor the founder of Islamic education in Minangkabau. Furthermore, Yunus stresses that it was Shaikh Burhanuddin al-Kamil (d. $610 \mathrm{H} /$ AD 1214) from Kuntu, a region in Kampar, who was the first spreader of Islam in Minangkabau. He came from the Arabian Peninsula with his friend, Abdul 
Alif. While Abdul Alif went directly to Aceh, Shaikh Burhanuddin went to Minangkabau. There he settled in Batuhampar, a small village in Payakumbuh, for ten years. Then he moved to Kumpulan in Bonjol. After teaching there for about five years, he moved to Ulakan and taught there for about fifteen years. Finally, he moved to Kuntu, a region in Kampar, and died there in $610 \mathrm{H} / 1214 \mathrm{AD}$ after having taught for twenty years."

Therefore, as far as Mahmud Yunus is concerned, Islam was introduced into Minangkabau more than 500 years before the coming of Shaikh Burhaduddin Ulakan. However, whether Shaikh Burhanuddin al-Kamil put the system of Islamic education as this was organized in 1680 into practice, by using the special place such as a surau for study, or whether he had his own system of Islamic education, has to remain a mystery for lack of evidence

Nevertheless, according to research carried out by the Indonesian Department of Education and Culture, Islamic education in the sense of the teaching and spreading of Islam began in Minangkabau from the coming of Islam to that area till the end of the seventeenth century. The period between the fifteenth century and the end of the sixteenth century is marked as the great Islamization era in Sumatra, because the Sultan of Aceh occupied most of the northeast part of Sumatra, such as Bugis, Pariaman, Talu, and so forth. Meanwhile, the conducting of Islamic education using special places for study began in $1680 .^{12}$ As mentioned above, the seventeenth century marks as the basis of the preaching Islam in Sumatra, and many students from area around the Aceh region went there to study. One of them was Burhanuddin from Ulakan, Pariaman. When he finished his studies in Aceh, he built a special place to study named a surau in 1680. As far as is known this was the first surau in Minangkabau. ${ }^{13}$ After this, Islam spreads to every region of Minangkabau through the preaching of Shaikh Burhanuddin's student, Tuanku nan Tuo, from Paninjauan in Padang Panjang. He mastered various Islamic disciplines, such as $\mathrm{Ma}$ 'ani, Nahwu, and Figh. After the death of Shaikh Burhanuddin Ulakan, Tuanku nan Tuo, helped by his student Fakih Sangir, suggested to the Minangkabau people that they abandon their bad customs and reject their adherence to the adat jahiliyah. ${ }^{14}$

By 1803, the atmosphere of Islamic education in Minangkabau changed, particularly after the retum of three Hajjis, Hajji Miskin, Hajji Sumanik and Hajji Piobang from Mecca. They saw it as their mission to spread the Hanafi madzab 
to which they had adhered in Mecca, and forced the people to relinguish their adat which was considered unsuitable to Islamic teachings. Unfortunately, they lacked tact and because of their radical ways not unnaturally many rebellions were fomented in Minangkabau. Strong opposition came from the kaum adat since they wanted to preserve their authority in adat. Later this movement was known as the Wahhâbi movement.

However, the research of the Department of Education and Culture points out that the Wahhâbi was not really a movement to reform Islamic education in Minangkabau, but it was rather an effort to purify religious understanding among the people of the area. They recommended that people not commit any kind of heresy in religious doctrines. This opinion is based on the fact that the Wahhâbi movement never used a surau as a centre for Islamic education as was done in the nineteenth century. ${ }^{15}$

The conclusion has to be that we cannot settle this complicated debate on the beginnings of the spread of Islam in West Sumatra. However, even if we adhere to the opinion that traces this moment back to as early as the twelfth century, we have no evidence about the nature of Islamic education in that period. However, we know that the first surau as the center of Islamic education was surau Ulakan in Pariaman which was established by Shaikh Burhanuddin Ulakan.

\section{The System of Education}

As mentioned above, as far as it is possible to trace historically it was Shaikh Burhanuddin who first founded an institution of Islamic education in Minangkabau. Once established this educational institutions then rapidly developed until the nineteenth century. It is not out of the question to find several sources dealing with the system of education in the nineteenth century, even so scanty, but to find sources before the nineteenth century is an enormous task. According to Karel Steenbrink, the reason for this was that the Dutch government disregarded the existence of the Islamic education system in its educational inspections. As a result, statistical data on the Islamic education are always incomplete. Even as late as 1927 it was not mentioned in the annual government report. ${ }^{16}$ 
Like Karel Steenbrink, Mahmud Yunus underscores that no data are available on the Islamic educational system in Minangkabau in the seventeenth, eighteenth, and the nineteenth centuries. However, he writes that some data about the end of the nineteenth century are available and these represent the situation in Islamic education prior to the Muhammadiyah reform. He calls this educational system the System Lama (the old system). In the following pages I shall give some details on this "old" Islamic educational system. ${ }^{77}$

Basically we can classify this old educational system into two levels. The first was the Pengajian al-Qur'ân. In this system teaching was conducted according to the halaqah system. Students sit in circles around the teacher. While listening to the explanation of the teacher, they write down notes in their books. Next, when the teacher reads the lesson aloud, the students repeat what is said word for word. ${ }^{18}$ This level can be subdivided into two classes, tingkat rendah and tingkat atas (basic class and advance class). In tingkat rendah the students learnt the Arabic alphabet by heart. Then, they learnt the marks kasrah, fathah and dhammah, and so on. They were then apply them by reading a short surah of Qur'ân. ${ }^{19}$ Students who successfully complete this step could continue their lessons by reading the Qur'ân right to the end. Striding ahead of the students in tingkat rendah, the students in tingkat atas were supposed to finish the recitation of the Qur'an. This was usually celebrated by a special ceremony called perayaan khatam Qur'ân. Students who passed this celebration could continue their study to 'Ilm al-tajwîd and the art of reading Qur'ân (qiraât). Moreover, they also learnt to perform various parts of $i b a d a h$, such as praying and fasting, Islamic ethics (akhlaq) and theology (aqidah). Beside that, under the old educational system, there was no time limit for students to complete their study. It all depended on the diligence and the intelligence of the students themselves. Consequently some students could finish their study in a short period of time, while others had to spend more time.

The second level is pengajian al-kitab (studying books). In this pengajian students learnt various old Arabic books in disciplines, such as 'ilm al-sharf, nahw, figh and tafsîr in-depth. These books had to be read one at a time. In other words, only after finishing book in 'ilm al-sharf the students were allowed to continue their study to other books. Mahmud Yunus claims that the Dhammun's book was the only book in 'ilm al-sharf at that time. This book was so old it was 
undated and knowledge of when precisely it was written had been lost. But it was used until1 $1900 .{ }^{20}$ The students had to master the contents of the book. After finishing this book, they continued their study by tackling the book al-Minhâj in 'ilm al-figh. Usually by this level the number of the students began to decrease because the lessons started to be hard to understand. Teachers just read the book in front of the students. Before continuing the lesson, they did not pause to ask whether or not the students had understood the previous lessons. Consequently, the lesson could only be followed by brilliant students. Students who could not follow this lesson would withdraw one by one from their class, meaning they left the surau without obtaining specific knowledge. In the meantime, the brilliant students could continue their lessons to analyse the book Jalalain in 'ilm tafsîr. 21

The method of teaching was still the halaqah system. The process of studying and teaching was the same as that in pengajian Qur'ân. It was just more advanced in the teaching material. The teachers read the book and translated the meaning of the words into the Malay language.

Moreover, it was a tradition in the old Islamic educational system that the students who had successfully completed all of their studies would become coteachers (guru tuo). ${ }^{22}$ They were permitted to teach the lower level student. In due time, when they had acquired enough Islamic knowledge, they would also permitted to build another surau in their village of origin. They again established the same Islamic educational system and had new students.

This then is a brief sketch of the development of the Islamic educational system in West Sumatra prior to the nineteenth century and it was still being used at the end of the nineteenth century when some Minangkabau students arrived home from Mecca and introduced their reform of Islamic education in Minangkabau.

According to Azyumardi Azra, during the sixteenth and seventeenth centuries there was already a network established between Indonesian 'ulamâ and those of Mecca and Medina (Haramain). ${ }^{23}$ Visiting these citjes in the pilgrimage many Indonesian 'ulamâ adopted the traditional Islamic discourses there and developed them in Indonesia on their retum. Therefore there can be no doubt that the Islamic educational system in Indonesia was influenced directly from Mecca. ${ }^{24}$ 
Mahmud Yunus states that the old educational system (pengajian lama) that was established in Indonesia was derived from that in Baghdad and Cairo at that time. ${ }^{25}$ As the capital city of the Muslim world, Baghdad had become a centre of knowledge. Many students from around the Muslim world studied there, including students from Indonesia. At this time, the progress of transportation technology facilitated their travelling to Mecca and Baghdad. As a result, after 1900 the Islamic educational system in Minangkabau changed. Many Minangkabau 'ulamâ such as H.M. Taib Umar, Shaikh Abdullah Ahmad, Shaikh Abdul Karim Amrullah, and Shaikh H.M. Djamil Djambek reformed several aspects of the Islamic educational system in Minangkabau, for instance the teaching material. ${ }^{26}$ The material of education was only limited not to 'ilm al-sharf, nahwu and tafsîr, but it stretched to 'ilm al-lauhîd, hadîth, mantîq, bayân, ma'âni, and figh. Along side this, many new Arabic books were also introduced such as alJurûmiyah, Asmawî, Azharî, Qatr al-Nadâ', and Alfịah in 'ilm al-Nahwu, al-Kailani and Taftanzani in 'ilm al-Sharf, Fath al-Qarib, Fath al-Mu'in, Iqna and Mahalli in 'Ilm al-Fiqh, and Tafsîr Jalallain, Baidhawi and Khazîn in 'ilm al-Tafsîr. Consequently, the book al-Dhammun and al-Awâmîl were laid aside.

The method of teaching was less affected, as in the old system, the halagah method remained in use. Mahmud Yunus argues even though it employed the system of education as that of the old one, that method successfully produced many famous 'ulamâ in Minangkabau because the quality of education in Minangkabau at that time was as good as that in the Middle East.

In short, the Islamic educational system in Minangkabau till the end of the $19^{\text {th }}$ century remained traditional. There were no well-arranged system and programme in education, and no good tools and proper equipment for teaching.

\section{The Institution of Islamic Education}

Untill the end of the nineteenth century the surau in Minangkabau played a prominent role in education. As an Islamic institution, it was different from the meunasah in Aceh or the maktab in Cairo. The surau was no longer just a place which children or unmarried men slept, instead it became the most important centre for Islamic teaching. It is a common phenomenon in the Muslim world 
that as soon as Islam takes roots in a particular society, educational centres are also established for the children of new converts. This is because education is the most practical way to strengthen the roots of Islam in a society. This holds true if we see the development of Islam in other regions, such as in Africa. In Africa Islam could only strengthen its roots after it adopted education as an important means of communication amongst its people. Accordingly, the oldest missionary organization in Africa, the Qadariyah, initiated its activity by teaching the people. ${ }^{27}$

In Minangkabau, as mentioned above, Shaikh Burhanuddin's surau was the first institution in West Sumatra. Its work in Islamic teaching, although it was done in a modest way, strengthened the roots of Islam in Minangkabau in its early development. Below, I shall mention some famous surau which have produced many 'ulamâs in West Sumatra.

1. Surau Tanjung Sungayang in Batusangkar. It was founded by Shaikh Taib Umar in AD 1897. Nowadays it is well-known as al-Hidayah S.M.P.I (PGA).

2. Surau Padang Japang in Payakumbuh. It was founded by Hajji Abbas Abdullah. Nowadays it is well-known as Darul Funun Abbasiyah.

3. Surau Jambatan Besi in Padang Panjang. It was founded by Shaikh Abdul Karim Amrullah in AD 1914. Nowadays it is well-known as Sumatra Thawalib.

4. Surau Candung Baso in Bukittinggi. It was founded by Shaikh Sulaiman alRusuli. Nowadays it is well-known as Tarbiyah Islamiyah.

5. Surau Jaho in Padang Panjang. It was founded by Hajji Jamil Jaho. Nowadays it is well-known as Tarbiyah Islamiyah.

6. Surau Tabat Gadang in Padang Japang. It is founded by Shaikh Abdul Wahid. Nowadays it is well-known as Tarbiyah Islamiyah.

7. Surau Parabek in Bukittinggi. It was founded by Shaikh Ibrahim Musa in AD 1908. Nowadays it is well-known as Thawalib. ${ }^{28}$

Furthermore, according to Azyumardi Azra, the surau in the sense of pesantren in Java and Madura or meunasah in Aceh, i.e. as an Islamic "boarding school", was represented by the surau of Shaikh Abdul Rahman in Batu Hampar, Payakumbuh. ${ }^{29}$ It provided thirty dormitories for students, namely Kampung 
Dagang which were built around the major building, the home of the Shaikh. Each surau was given the name of the students' village of origin, for instance surau Tilatang Kamang, surau Solok and surau Suliki. ${ }^{30}$

The main building was Masjid Dagang which was used for praying and reciting the Qur'ân led by Shaikh Abdul Rahman. Besides this, there were also two buildings near the Masjid Dagang that were used for practising suluk and as a dormitory for guests. Behind them was a special cemetery for the Shaikh and his ancestor. ${ }^{31}$ Meanwhile, to provide the daily necessities of the students, the Shaikh also arranged a shop for students, a place where students could buy what they needed, such as books. pencils, and pens. In shor, Shaikh Abdul Rahman's surau was the most outstanding one in its set up and equipment for study.

Furthermore, at the end of the nineteenth century or in the initial years of the twentieth, the Islamic educational institutions in Minangkabau gradually began to change their function. The return of many 'ulamâ from Mecca bringing new ideas initiated this change. Those "ulama and with their students gradually spread the thoughts of Muhammad Abduh and Rashid Rida on Islamic modermization. ${ }^{32}$ In imitation of al-Manâr in Egypt and Mecca, the magazine al-Munîr was issued to carry on the same mission. ${ }^{33}$ Consequently, many Minangkabau people became conscious of their lack of education and religious understanding. They realized the importance of Islamic education in eliminating taglid thinking and jumud. As a result, the number of students as well as halagah circles in surau increased. Eventually the surau were no longer adequate as a place in which Islamic education could be propagated. A much larger establishment was needed which later became known as madrasah. ${ }^{34}$

The same holds true if we see other parts of Muslim world, such as Cairo. In Cairo mosques which were the first educational institution in the early period of Islam gradually changed into madrasah, since mosques, mainly built for worship where everyone should be quiet, were no longer proper places to house hundreds of students. As the number of students increased, this also required that the circle of halaqah be improved too. Consequently, according to Ahmad Shalaby, given the circumstances the change of the place study from mosque to madrasah was natural..$^{35}$ 
Von Kramer adds that the progress and diffusion of knowledge created a body of men who found it difficult to make a decent living from their abstract learning. Therefore madrasah were established with twofold purpose: to promote further study and to provide sufficient stipends for such men. ${ }^{36}$

In Minangkabau by the early twentieth century many surau had been changed into madrasah. Mahmud Yunus says that, Sumatra Thawalib in Padang Panjang was the first surau that used the class system. ${ }^{37}$ It was then followed by Sumatra Thawalib Parabek in Bukittinggi and Sumatra Thawalib in Maninjau. The new education system was introduced in these madrasah, so that classes were categorized into seven stages. Consequently, it no longer used the halaqah system and its curriculum extended beyond mere religious studies. ${ }^{3 .}$

Furthermore, new madrasahs were also created. The Adabiyah school was the first school in Minangkabau which to offered religious studies in its curriculum. This school already used chairs and blackboards. It was founded by Shaikh Abdullah Ahmad in 1907. But after a short time, it was closed because many Minangkabau people would not accept its system which they though was too similar to the Dutch school system. ${ }^{39}$ Abdullah Ahmad then moved to Padang and built the second Adabiah School in 1909. This school was readily accepted in Padang because the people there were more tolerant. Later, in 1915 Abdullah changed his school's name to the Hollandsch Inlandsche School Adabiah because it adopted the Dutch school system totally and received financial aid from the government. Besides that, the principal of this school was a Dutchman, who was assisted by two Dutch teachers. ${ }^{40}$

By 1910 Shaikh Taib Umar also established a madrasah in Sungayang namely the Madras School. Unfortunately, in 1913 this school was closed because of financial difficulties ${ }^{41}$ However, in 1918 Mahmud Yunus opened it again and renamed it the Dinivah School in 1923. Recently it has become well-known as Al-Hidayah Islamiyah and S.M.P/P.G.A.P. ${ }^{42}$

On October 10, 1915 a Dinivah School was opened in Padang Panjang. It was founded by Zainuddin Labai al-Yunusiah. ${ }^{43}$ Unlike the Adabiyah School, the Diniyah School was still conducted in a mosque. Despite this it already used the new system based on the Dutch system, with classes, blackboards, and chairs. The students wore pantalons, jackets, and ties. In the curriculum, both religious and secular subjects were given. Among the secular subjects were Dutch and 
English language, math and geography. ${ }^{44}$ For religious subject, new books were imported from Egypt. For the first time the number of students were 150. Male students were placed on the left side of the mosque and were taught by Engku Haji Mahmud and Haji Sholeh. The female students were placed on the right side of the mosque and were tought by Zainuddin Labai al-Yunusiah. ${ }^{45}$

This school was divided into two levels; Ibtidaivah and Thanawivah. In Ibtidaiyah the students learnt the book Durûs al-Fiqhiyah and Mabâdi' 'Arabiyah, while in Thanawiyah they learnt the book Aqâ'id Diniyah and Irsyâd al Murîd which were written by Zainuddin Labai. In addition, books from Egypt were also studied. ${ }^{46}$

Nevertheless, the rise and growth of Islamic institutions prior to the twentieth century in Indonesia, especially in Minangkabau, did not come about simply because of the influence of Islamic reform ideas, it was also encouraged by the Dutch government policy in education at that time. As we shall see, the government gave priority in the opportunity to study only for Dutch children. The reason for this, as mentioned by Sorimuda Nasution, was that the policy of the Dutch government was to respect the natives and their institutions, and leave the population under the direction of their own chiefs. Another reason may have been the great financial difficulties faced by the Dutch government as a consequence of the expensive and bloody Diponegoro war (1825-1830), followed by the conflict between them and Belgium from 1830 to $1839 .{ }^{47}$ It was true that in 1808 , on the initiative of Daendels, the government built a school for native people, but the school was financed by the nagari community. ${ }^{48}$ Besides, as a result of the Ethical Policy (1900-1920), the Dutch government operated a school system that was designed to train lower government officials and to eradicate illiteracy. This school was then called a second-class school. Admission was limited to certain students whose parents worked in the government. ${ }^{49}$

In the early 1910s, the introduction of the volksschool (Sekolah Rakyat) by the government resulted in a rapid expansion of the educational system in Minangkabau. By 1913 there were 111 volksschoolen and by 1915 the number increased to $358 .{ }^{50}$ The upshot was that the number of students in surau decreased gradually. Consequently, many teachers of tarekat condemned this school system and regarded it as a sinful school (sekolah dosa). ${ }^{51}$ 
Although many schools were directly under government control, their financial affairs were still the responsibility of the local government..$^{52}$ According to K.A. James, Kota Gedang, a small nagari near by Bukittinggi, produced a large number of teachers and government officials. By 1911, through its own locally financed Study Fund it sent two students to Holland for advanced education. In 1914 the nagari had its own Dutch school (H.I.S)..$^{53}$

\section{E. Conclusion}

This survey has shown that there were many Islamic institutions in Minangkabau prior to the twentieth century. Their rise and development was stimulated not just by the influence of the educational ideas of reform in the Muslim world, but because the policy of the Dutch government. As mentioned above, the surau, as the first Islamic centre in education, was no longer a suitable place in which to teach. but the policy of the government prohibited Islamic matters being taught in schools. Consequently, many Islamic institutions rose and created their own identity in an educational system, differing widely from the Dutch educational institutions.

\section{Endnotes}

I Mahmud Yunus was born at Batusangkar, a region in West Sumatra, in 1890. He taught religion at Dinivah School (previously known as the Madras School) in Sungayang from 1918 and edited its journal al-Bashir from 1920 before going to Cairo in 1925. Returning to his native village in 1930, he was made principle of the Nomal Islam, created by the Persatuan Guru-Guru Agama Islam (P.G.A.I. or Islamic Teachers" Association) in Padang in 1930. See, Federspiel, Howard, M., "The Muhammadiyah: A Study of an Orthodox Islamic Movement in Indonesia", in Indonesia, no. 9, April 1970, Cornell Modern Indonesia Project, p. 76.

= Yunus, Mahmud, Sejarah Pendidikan Islaw di Indonesia, Jakarta, Hidakarya Agung. 1983,p. 10.

3 G.W.J. Drewes. "New Light on the Coming of Islam to Indonesia?" in Ahmad Ibrahim. Sharon Siddique and Yasmin Hussain (compilators), Readings on Islam in Southeast Asian, Institute of Southeast Asia Siudies, 1985, p. 8; Azra, Azyumardi, Jaringan 
Ulama Timur Tengah dan Kepulauan Nusantara Abad XVII dan XVIII, Bandung, Mizan, p. 24.

4 Hurgronje, C. Snouck, Verspreide Geschrifien, Den Haag, Nijhoff, 1924, pp. 7-9.

5 Moquette, J.P., "De Grafsteenen te Pase en Grisse vergeleken met dergelijke monumenten uit Hindoestan" TBG, 54, 1912, pp. 536-548.

6 Al-Attas, S.M.N., Preliminary Statement on a General Theory of the Islamization of the Malay-Indonesian Archipelago, Kuala Lumpur, Dewan Bahasa dan Pustaka, 1969, pp. 1-25.

7 Hasjimi, A., Sejarah Masuk dan Berkembangnya Islam di Indonesia, Bandung, AlMaarif, 1989, p. 7; Hasjmi, A., Sejarah Kebudayaan Islam di Indonesia, Jakarta, Bulan Bintang, 1990, p. 4.

* Hamka, Sinamya Islam di Soemarra, Medan. Badan Pembangunan Semangat, 1945, p. 8 .

y It is said that the name of Shaikh Burhanuddin Ulakan was Pono. He was born in Pariangan, Padang Panjang, in a Buddhist family. He was converted to Islam through a trader from the Gujarat named Illappai. Because of his religion, he was exiled by his fellow villagers and moved to Siantuk in 1029 H/1599 AD. From Siantuk he continued his journey to Ulakan and studied there with Angku Madinah from Aceh. After finishing his studies in $1032 \mathrm{H} / 1601 \mathrm{M}$. Angku Madinah suggested him to study directly under Abdul Rauf in Aceh. He died on Wednesday, Safar 10, $1111 \mathrm{H}$. His grave is visited specially every 10 Safar by many people who considered him as a wali. In Minangkabau this custom is widely known as basafa. For further discussion see Gazalba, Sidi, Mesjid Pusat Ibadat dan Kebudayaan Islam, Jakarta, Pustaka alHusna, 1989, p. 279; Zein, Abdul Baqir, Masjid-Masjid Bersejarah di Indonesia, Jakarta, Gema Insani Press, 1999. pp. $42-44$.

10 Yunus, Mahmud. Sejarah Pendidikan, pp. 20-21.

11 Yunus, Mahmud, Keringkasan Sejarah Islain di Minangkabau, Djakarta, CV AlHidayah, pp. 20-21.

12 Departemen Pendidikan dan Kebudayaan. Sejarah Pendidikan Daerah Sumatra Barat, 1980/1981, p. 71.

13. Even though the term of surau was known by the Minangkabau people before the coming of Islam, its function was just limited to a place for sleeping and gathering of young people, unmarried men and old people. The adat of Minangkabau demanded that young and unmarried men be shy of sleeping in one house with their parents and sisters. A surau usually belonged to a kaum or suku and provided a place for people of the same line to gather in order to make decisions. According to Sidi Gazalba the word surau is derived from Arabic word syura meaning deliberation. See Gazalba, Sidi, op. cit., pp. 314-318; Azra, Azyumardi, "Surau di Tengah Krisis: Pesantren 
dalam Perspektif Masyarakat", in Rahardjo, M. Dawam (ed), Pergulatan Dunia Pesantren, Jakarta, P3M, 1985, p. 156.

14 Before the coming of Islam into Minangkabau, many Minangkabau people still adhered to some reprehenside customs, such as gambling, drinking, belief in spirits and devils, under the influence of Hindus Kingdom Pagaruyung from 1347 to 1809 . For further discussion see Mansoer, M.D., Sedjarah Minangkabau, Jakarta, Bhratara, 1970, pp. 119-120; Hamka, Ayahku Riwayat Hidup Abdul Karim Amrullah dan Kaum Agama, Djakarta, Widjaya, 1950, p. 12; Taufik Abdullah, "Islam, History, and Social Change in Minangkabau", in Change and Continuity in Minangkabau, Local, Regional, and Historical Perspectives on West Sumatra, Ohio University, Monograph in Intenational studies Southeast Asia Series, no. 71, pp. 141-157.

15 Departemen Pendidikan dan Kebudayaan. op .cit., p. 76.

16 Although it is true that statistics have been kept since 1874 , they were not complete and they were merely repetitions of previous figures, viz. around 20.000 institutions and 300,000 pupils. See Steenbrink, Karel, Pesantren, madrasah, Sekolah, Pendidikan Islam dalam Kurun Modern, Jakarta, LP3S, 1986, p. 9

17 See Yunus, Mahmud, Sejarah Pendidikan, p. 34.

18 Snouck Hurgronje says that various voices could be heard in this halagah system because pupils had to read their lessons a loud. Although it was noisy, they did not disturb each other. See Hurgronje, C. Snouck, Een en ander over het inlandsch onderwijs in de Padangsche Bovenlanden, in VG IV, I, pp. 27-52.

19 See Iskandar. N. St, Pengalaman Masa Kecil. Jakarta, Balai Pustaka. 1987, p. 16.

20 Mahmud Yunus argued that Kitab al-Dhammun might have been written by Indonesian 'ulamâ. His opinion was based on the fact that the translation of Arabic words in the book was in Malay script. Unfortunately there is no further description of this book. See Yunus, Mahmud, Sejarah Pendidikan, p. 43.

21 According to Mahmud Yunus's teacher, Thaib Umar, the halaqah method could produce but one fine 'ulama' out of a hundred students. See Yunus, Mahmud, ibid., p. 50 .

22 See Iskandar, N. St. op. cit., p. 16.

23 See Azra, Azyumardi, op. cit., p. 59.

24 A number of scholars are of the opinion that the Islamic educational system of Indonesia was adopted from India. They argue that some aspects of the Islamic educational system existed in Hindu teaching before the coming of Islam to the Indonesian Archipelago. For instance, the terms mengaji and langgar (in Java), surau (in Minangkabau), and rangking (in Aceh) are Sanskrit terms rather than Arabic terms. In addition, the giving of special land by devoted men for educational 
institutions is also evidence of Hindu influence. The living tradition of Hinduism, such as the respect of students toward teachers and looking for financial aid from their neighbours is clearly in evidence. For further discussion see Steenbrink, A Karel, op. cit., p. 30; Hutasoit, M., Compulsory Education in Indonesia, UNESCO, 1954, pp. 17-18.

25 Yunus, Mahmud, op cit., p. 53. By 1925, according to William R. Roff, there were at least two hundred Southeast Asian students in the city. See Roff, R.William, "Indonesian and Malay Students in Cairo in the 1920"s", in Indonesia, no. 9, April 1970, Cornell Modern Indonesian Project, p. 74.

26 Ibid.

27 Yeoh, Siok Cheng, Umara'Ulama-Ummat Relation and Pesantrens in Aceh Prolince Indonesia: A Study of the Challenges to the Authority of A Traditional, Ph.D. Dissertation, Ann Arbor, University of Washington, 1994, p. 33-34.

28 Yunus, Mahmud, op. cit., p. 60.

29 Shaikh Abdul Rahman was born in 1777 in Batu Hampar and died in 1899. He was a grandfather of M. Hatta, the first vice- president of Indonesia. After studying fourtyeight years with many famous 'ulama' in Mecca, he established the first surau in his natal village. After his death, his surau was led by his son Shaikh Arsyad. Recently it has been led by his grandson, Shaikh Dhamrah Arsyad. Even though nowadays surau have generally lost their significant influence, surau Shaikh Abdul Rahman has produced many famous 'ulamâ' in Minangkabau.

30 Like santri in pesantren, students in surau were called orang siak. Meanwhile the kiyai was called Shaikh. The number of orang siak in Abdul Rahman's surau was about 1,000 to 2,000. There were no clear classification of age or time limit on students study. The completion of their study depended on their intelligence.

3) See Azra, Azyumardi, "Surau di Tengah Krisis: Pesantren dalam Perspektif Masyarakat", in M. Dawam Raharjo (ed), Pergulatan Dunia Pesantren Membangun dari Bawah, Jakarta, P3M, 1985, pp149-174.

32 Hutasoit, M, Compulsory Education in Indonesia, Paris, United Nation Educational, Scientific and Cultural Organization (UNESCO), 1954, pp. 17-20.

33 Mahmud Yunus says that, Al-Munî was the first Islamic magazine in Minangkabau. It was printed in Padang by Shaikh Thaib Umar in 1911. It contained numerous articles religious and secular matters, questions and answers, and news about Muslim world. It encouraged Muslims to seek knowledge. See Yunus, Mahmud, op. cit., p. 63.

34 Abdullah, Taufik, School and Politics: The Kaum Muda Movement in West Sumatra (1927-1933), unpublished dissertation, New York, Cornell Modern Indonesia Project 
Southeast Asia Program, Ithaca, 1971, p. 55; Azra, Azyumardi, "Surau di Tengah Krisis", p. 165.

Shalaby, Ahmad, History of Muslim Education, Beirut, Dar al-Kashshaf, 1954, p. 55.

Bukhsh, Khuda, Contribution to the History of the Islamic Civilization, Calcutta, 1905, p. 219.

37 Sumatra Thawalib originated from surau Jembatan Besi. The name was derived from an iron bridge located close by this surau. See Daya, Burhanuddin, Gerakan Pembaharuan Penikiran Islam Kasus Sumatra Thawalib, Yogyakarta, Tiara Wacana, 1990, p. 81; Abdullah, Taufik, School and Politics. The Kaum Muda Movement in West Sumatra 1927-1933, Cornell University, Ithaca, 1971, p. 56. According to M.D. Datuk Palimokayo this surau already existed before 1900 and Shaikh Abdullah was its first teacher. See Palimokayo, M.D. Datuk, Sejarah Perguruan Thawalib Padang Panjang, Yavasan Thawalib Padang Panjang, 1970, p. 5. In contrast to Palimokayo, Mahmud Yunus wrote that this school was established by Haji Rasul in 1914. See Yunus, Mahmud, Sejarah Pendidikan Islam di Indonesia, p. 60. While Hamka, claims that this surau was established by Abdullah Ahmad. When Haji Rasul came from Mecca in 1904, he started to teach students in Maninjau, his village of origin and in surau Jembatan Besi after a request from Abdullah Ahmad. One of his students was Zainuddin Labai al-Yunusiah. See Hamka, Avahku. Riwayat Hidup Abdul Karim Amrullah dan Perjuangan Kaum Agama, Jakarta, Widjaja, 1950, p. 100. Nowadays surau Jembatan Besi is well- known as Masjid al-Zu' ama'.

Yunus, Mahmud, Sejarah Pendidikan Islam di Indonesia, p. 73.

At that time the Minangkabau people till strictly held the farw \%o of 'ulama which stated that whosoever imitates one community, he is amongst them. So it was absolutely forbidden to imitate the kafir behaviour, such as wearing a tie, a cap, and including new tools in education. See Sejarah Adabiah, p. 2; See also Steenbrink, Karel A., Pesantren, Madrasah, Sekolah, Pendidikan Islam dalam Kurun Modern, p. 39 .

This initiative of Abdullah Ahmad led to a polemic in Minangkabau. His contemporaries called him a hollandisator particularly when he recognized the Guru Ordonnantie (teacher ordinance which stipulated that anyone wishing to give instruction on the Islamic teaching to person other than his immediate family should inform the regent, or patih, in Java or the district chief in the Outer Region) in 1925. See Steenbrink, Karel A., Pesantren, p. 37-41; Daya, Burhanuddin, Gerakan Pembaharuan, p. 83. According to Deliar Noer, the identity of the Adabiah school as the mobilisator of Islamic education was dropped. Like another H.I.S. in Minangkabau, it no longer laid full attention to religious studies. As far as he was concerned the fame of the Adabiah school was that it was the first school in Minangkabau which was founded 
by native people. See Noer, Deliar, The Modemist Muslim Movement in Indonesia 1900-1942, London, New York, Oxford University Press, 1973, p. 52.

41 Yunus, Mahmud, op. cit., p. 63; Daya, Burhanuddin, Gerakan Pembaharuan, p. 84.

42 Islamic Center Sumatra Barat, Riwayat Hidup 20 Ulama Sumatra Barat, Padang, p. 186-195.

43 Zainuddin Labai al-Yunusiah was born in Bukit Surungan, a small village in Padang Panjang in 1890. He was a self-taught person mastering various Islamic and secular matters. He just studied four years in a formal school, but wrote many books such as, 'Aqâ'id al-Binsah, Ma'bâd al-Arba'ah, Irshâd al-Murîd, al-Durûs al-Fighiyah, and Adâb al-Fath. He died on July 20,1924. See Peringatan 55 Tahun Diniyah Putri Padang Panjang, Ghalia Indonesia, p. 44-45; Daya, Burhanuddin; op. cit., p. 84; Steenbrink, Karel A., op. cit., p. 43-50; Noer, Deliar, op. cit., p. 48-49.

44 The ideas of reform of Zainuddin Labai al-Yunusiah triggered of a heated attack from the traditional Muslims particularly concerning the co-educational system which combined the male and female students in one class. See Peringatan 55 Tahun, p. 44; Steenbrink, Karel A., Pesantren, p. 47.

45 Because of the lack of appropriate places of study, Dutch government offered financial aid to Zainuddin Labai. Unlike the Adabiyah School which received the offer, Diniyah School did not accept it. See Hamka, "Saya Teringat", in Peringatan 55 Tahun, p. 293-299.

46 Yunus, Mahmud, Sejarah Pendidikan Islam, p. 66; Daya, Burhanuddin, Gerakan Pembaharuan, p. 84.

47 It was said that the government was responsible only for the making of regulations without the obligation to provide schools. As a result, the number of Indonesian students was very limited. According to a report of the head commission of education in 1874, they numbered only 37 out of 1700 pupils. See Nasution, Sorimuda, The Development of the Public School System in Indonesia: 1892-1920, Published dissertation, University of Wincosin, 1967, p. 37; Saridjo, Marwan, Sejarah Pondok Pesantren di Indonesia, Jakarta, Dharma Bhakti, 1980, p. 42.

48 See Nasution, Sorimuda, op. cit., p. 35-36.

49 See Hutasoit, M., Compulsory Education in Indonesia, IBE-UNESCO publication, 1954 , p. 20.

so See Ballot, J., "Memorie van Overgave", in Verbaal, April 5, 1916, no. 15, p. 83-87; Buchari, Ibrohim, Pengaruh Timbal Balik antara Pendidikan Islam dan Pergerakan Nasional di Minangkabau, Jakarta, Gunung Tiga, 1982, p. 69.77; Abdullah, Taufik, School and Politics, p. 10-11; Daya, Burhanuddin, Gerakan Pembaharuan, p. 85. 
51 See M.V.O. van den Aftreden den Gouverneur van Sumatra's Westkust, W.P.C. Whitlop, Padang, April 1921, p. 42.

52 Netherlands Indies, Hollandsch-Inlandsch Onderwijs Commissie, Publicaties, no. 9, Batavia, 1913, pp. 15-16; van der Veur, Paul W., Education and Social Change in Colonial Indonesia (1). Progress and Procrastination in Education in Indonesia Prior to World War II, Ohio University, 1969, p. 2.

53. See James, K.A., “De Nagari Kota Gedang”, TBB, no. 49, 1915, p. 185.

\section{Bibliography}

Abdullah, Taufik, "Islam, History, and Social Change in Minangkabau", in Change and Continuity in Minangkabau, Local, Regional, and Historical Perspectives on West Sumatra, Ohio University, Monograph in Intenational Studies Southeast Asia Series, no. 71.

Abdullah, Taufik, School and Politics: The Kaum Muda Movement in West Sumatra (1927-1933), unpublished dissertation, New York, Cornell Modern Indonesia Project Southeast Asia Program, Ithaca, 1971.

Al-Attas, S.M.N., Preliminary Statement on a General Theory of the Islamization of the Malay-Indonesian Archipelago, Kuala Lumpur, Dewan Bahasa dan Pustaka, 1969.

Azra, Azyumardi, Jaringan Ulama Timur Tengah dan Kepulauan Nusantara Abad XVII dan XVIII, Bandung, Mizan, 1985.

Azra, Azyumardi, "Surau di Tengah Krisis: Pesantren dalam Perspektif Masyarakat", in Rahardjo, M. Dawam (ed), Pergulatan Dunia Pesantren. Jakarta, P3M, 1985.

Azra, Azyumardi, "Surau di Tengah Krisis: Pesantren dalam Perspektif Masyarakat", in Rahardjo, M. Dawam (ed), Pergulatan Dunia Pesantren, Jakarta, P3M, 1985.

Ballot, J., “Memorie van Overgave”, in Verbaal, April 5, 1916, no. 15.

Buchari, Ibrohim, Pengaruh Timbal Balik antara Pendidikan Islam dan Pergerakan Nasional di Minangkabau, Jakarta, Gunung Tiga, 1982. 
Bukhsh, Khuda, Contribution to the History of the Islamic Civilization, Calcutta, 1905.

Daya, Burhanuddin, Gerakan Pembaharuan Pemikiran Islam Kasus Sumatra Thawalib, Yogyakarta, Tiara Wacana, 1990

Departemen Pendidikan dan Kebudayaan, Sejarah Pendidikan Daerah Sumatra Barat, 1980/1981.

Federspiel, Howard M., "The Muhammadiyah: A Study of an Orthodox Islamic Movement in Indonesia", in Indonesia, no. 9, April 1970, Cornell Modern Indonesia Project.

Gazalba, Sidi, Mesjid Pusat Ibadat dan Kebudayaan Islam, Jakarta, Pustaka al-Husna, 1989.

G.W.J. Drewes, "New Light on the Coming of Islam to Indonesia?" in Ahmad Ibrahim, Sharon Siddique and Yasmin Hussain (compilators), Readings on Islam in Southeast Asian, Institute of Southeast Asia Studies, 1985.

Hamka, Sinarnya Islam di Soematra, Medan, Badan Pembangunan Semangat, 1945.

Hamka, Ayahku. Riwayat Hidup Abdul Karim Amrullah dan Perjuangan Kaum Agama, Jakarta, Widjaja, 1950.

Hasjimi, A., Sejarah Masuk dan Berkembangnya Islam di Indonesia, Bandung, Al-Maarif, 1989.

Hasjmi, A., Sejarah Kebudayaan Islam di Indonesia, Jakarta, Bulan Bintang, 1990.

Hurgronje, C. Snouck, Verspreide Geschrifien, Den Haag, Nijhoff, 1924.

Hurgronje, C. Snouck, Een en ander over het inlandsch onderwijs in de Padangsche Bovenlanden, in VG IV, I.

Hutasoit, M., Compulsory Education in Indonesia, UNESCO, 1954.

Iskandar, N. St, Pengalaman Masa Kecil, Jakarta, Balai Pustaka, 1987.

James, K.A., "De Nagari Kota Gedang”, $T B B$, no. 49, 1915.

Junus, Mahmud, Sejarah Pendidikan Islam di Indonesia, Jakarta, Hidakarya Agung, 1983.

Mansoer, M.D., Sedjarah Minangkabau, Jakarta, Bhratara, 1970. 
Moquette, J.P., "De Grafsteenen te Pase en Grisse vergeleken met dergelijke monumenten uit Hindoestan" TBG, 54, 1912.

Nasution, Sorimuda, The Development of the Public School System in Indonesia: 1892-1920, Published dissertation, University of Wincosin, 1967.

Netherlands Indies, Hollandsch-Inlandsch Onderwijs Commissie, Publicaties, no. 9, Batavia, 1913.

Noer, Deliar, The Modernist Muslim Movement in Indonesia 1900.1942, London, New York, Oxford University Press, 1973.

Palimokayo, M.D. Datuk, Sejarah Perguruan Thawalib Padang Panjang, Yayasan Thawalib Padang Panjang, 1970.

Roff, R.William, "Indonesian and Malay Students in Cairo in the 1920's", in Indonesia, no. 9, April 1970, Comell Modern Indonesian Project.

Saridjo, Marwan, Sejarah Pondok Pesantren di Indonesia, Jakarta, Dharma Bhakti, 1980.

Shalaby, Ahmad, History of Muslim Education, Beirut, Dar al-Kashshaf, 1954.

Steenbrink, Karei, Pesantren, madrasah, Sekolah, Pendidikan Islam dalam Kurun Modern, Jakarta, LP3S, 1986.

van der Veur, Paul W., Education and Social Change in Colonial Indonesia (1). Progress and Procrastination in Education in Indonesia Prior to World War Il, Ohio University, 1969.

Yeoh, Siok Cheng, Umara >Ulama-Ummat Relation and Pesantrens in Aceh Province Indonesia: A Study of the Challenges to the Authority of A Traditional, Ph.D. Dissertation, Ann Arbor, University of Washington, 1994.

Yunus, Mahmud, Keringkasan Sejarah Islam di Minangkabau, Djakarta, CV Al-Hidayah.

Zein, Abdul Baqir, Masjid-Masjid Bersejarah di Indonesia, Jakarta, Gema Insani Press, 1999. 